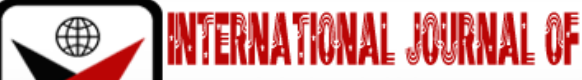

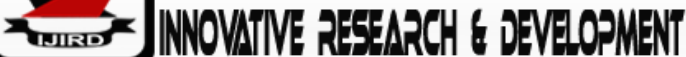

ISSN $2278-0211$ (Online)

\section{Nigeria’s Border Closure: Implications for Africa Continental Free Trade Area Agreement}

\begin{tabular}{|c|}
\hline $\begin{array}{c}\text { Oni Timothy Olukunle } \\
\text { Associate Research Professor, Department of Agriculture and Food Policy, } \\
\text { Nigerian Institute of Social and Economic Research (NISER), Nigeria } \\
\text { Jerumeh Tolulope Rachael } \\
\text { Research Fellow, Department of Agriculture and Food Policy, } \\
\text { Nigerian Institute of Social and Economic Research (NISER), Nigeria } \\
\text { Nathan Williams } \\
\text { Junior Research Fellow, Department of Agriculture and Food Policy, } \\
\text { Nigerian Institute of Social and Economic Research (NISER), Nigeria }\end{array}$ \\
\hline
\end{tabular}

\section{Abstract:}

African Continent Free Trade Area Agreement (AFCFTA) has long been considered as a mechanism for accelerating economic growth and engendering visible reductions in income inequality. Trading activities under the AFCFTA arrangement was expected to kick start in July 2020 but recent developments suggest that the implementation may be slowed down. The closure of Nigerian border barely 3 months after signing the pact is an indication of the low level of preparedness and commitments by most member states. The argument in favour of the border closure is further strengthened by the current reality of Coronal virus pandemic which suddenly hit the world's population. Moving forward, Nigeria's actions render the seriousness and prospects of regional integration in Africa a little doubtful. Apart from diverting focus from areas that can enhance free trade agreement such as trade data capture, transportation infrastructure, and border protection, the Nigeria's border closure may dampen the enthusiasm of other countries towards the free trade deal. The effect of the land closure placed a downward strain on the national income and GDP of Nigeria's neighbouring countries particularly Benin republic, Niger republic, Cameroun and Ghana. As a way forward, AFCTA should encourage member countries to diversify and specialize in the production of goods for which they have comparative advantage in order to deepen intra-African and intra-regional trade and for participating countries to benefit from economies of scale.

Keywords: AFCTA, border closure, regional integration, Nigeria, African countries

\section{Introduction}

Although Africa represents $16 \%$ of the total world's population, it only accounts for $5 \%$ of global income with about half of its population classified as low income and the rest as middle income (55.4\%) or high income (0.01\%) (Darma, 2019). More than half of the world's extreme poor people (living on less than $\$ 1.9$ a day) are in sub-Saharan Africa. Therefore, reducing extreme poverty across the continent is and continues to constitute a top policy concern. In recent times, one of the important and direct shot at poverty reduction is the African Continent Free Trade Area Agreement (AFCFTA) which has long been considered as a mechanism for accelerating economic growth and engendering visible reductions in income inequality. The African Continental free Trade Agreement (AFCFTA) is one of the pilot initiatives of 2063 African Union (AU) Agenda which is targeted at establishing a single continental market for the exchange of goods and services without entrance restriction on the movement of business professionals and investments (Onwuka and Udegbunam,2019).The Agreement establishing the AFCTA was signed by 44 countries out of the 55 AU member countries at the summit held in Kigali, Ruwanda, 17th -21 March, 2018 (Ighobor, 2018).

The main objectives of the AFCFTA as highlighted by Cofelice (2018) are to promote intra-African trade and regional value chains to increase Africa's competitiveness in the global economy, increase innovation, industrialization and continental market access, all of which substantially accelerate economic growth and social progress. If fully implemented, the agreement is expected to facilitate intra-African trade to create the world's largest single market of 1.2 billion with a cumulative GDP in the excess of $\$ 3.4$ trillion (IMF, 2019). In furtherance, a recent report by United Nations Economic Commission for Africa revealed that the implementation of AFCFTA will increase intra-African trade by $52 \%$ in 2020 from its value in 2010, thereby narrowing down the gap with intraregional trade quotas which is presently pegged at 51\%, 54\% and $67 \%$ for Asia, North America and Europe, respectively (Cofelice,2018). However, in the short run, a number of associated costs have been identified with trade integration with more significant consequences on countries with small economies. These in the African context include uneven distribution of benefits and costs among member States, adjusting 
unemployment, tariff revenue losses, regulatory and political reforms, threat to local industries, infrastructural investment, among others (Saygili et al, 2019).

Moving forward, the operational phase of the AFCFTA was launched on the 7th July, 2019 which had Nigeria and Republic of Benin as new signatories leaving Eriteria as the only country yet to sign the pact. Trading activities under the AFCFTA arrangement is expected to kick start in July 2020 but recent developments suggest that most African countries are not fully prepared for its implementation (Signe and van der ven, 2019). For example, the closure of Nigerian border after 3 months of signing the pact is an indication of the low level of preparedness and commitments by most member states. The Nigeria's border closure also contravenes her commitment with Economic Community of West African States (ECOWAS) which is supposed to cover a period of 44 years during which there should be no quotas, custom duties or quantity restrictions among the member states (Signe and van der ven, 2019). However, the border policy became necessary for the Nigerian government given the increased rate of criminality recorded at the borders which come in form of smuggling, trafficking (drug and human), religious carnage fuelled by imported extremism and the resulting deaths of innocent Nigerians and threat to state security and stability (Adeola and Oluyemi,2012). More importantly, the border closure was introduced to restrict informal trade of staple food commodities (especially rice, flour, groundnut oil, and perishables such as tomatoes, and frozen foods.) between Nigeria and the surrounding countries. Smuggling has been a major challenge faced by Nigeria, a report by the Senate Committee on Customs, Excise and Tariff in 2017, revealed that goods valued at over N7 trillion are being smuggled into Nigeria annually, an act which poses serious threat to Nigeria's self-sufficiency especially in the production of rice (Rodl and Partner, 2019). In recent times, the basis for border closure has been further strengthened by the Coronavirus pandemic which has killed over 16,000 and sickened several thousands of people. In response to this, the Nigerian government, like other countries, ensured stricter restriction on the movement of people in and out of the country.

The border closure has important implications for both Nigeria and the neighbouring countries. As expected, there was a sharp increase in the consumer price of virtually all the affected goods. For instance, the report by National Bureau of Statistics, the border closure has led to increase in consumer price index from 13.2\% in August 2019 to 14.09\% in October, 2019 (Abia, 2020). However, this has increased the custom revenue realisable by the Nigerian Custom service. In the light of this, the Comptroller General of the Nigerian Customs Service (NCS) revealed that cargoes that were normally shipped to some neighbouring countries particularly Benin and later discharged into Nigeria through illegal routes are now being directed to relevant port authorities where duties are collected and as a result custom daily revenue increased from 4.7 to 5.8 billion naira (Rodl and Partner, 2019). Nonetheless, unless the border closure policy is complimented by corresponding growth in domestic production, the federal government should not be quick to consider the revenue increase from the border closure as an additional source of income because the supposed increase is just the redistribution of income from the citizens, paying higher prices for the goods, to the government who earns it back in form of custom duties.

Although the borders may not be reopened soon due to the pandemic, but whenever this is done, new rules concerning local input components and originality of all imported goods, trading activities strictly enroute the Nigerian borders and human passports are to be set. However, since the borders are still closed, the paper therefore seeks to understand how border closure will affect regional and international trade treaties with special focus on the AFCTA.

\section{Method}

\subsection{Framework Used for Analysis}

The paper is based on desk review of literature and the theoretical anchor of the paper is the theory of economic integration as put forth originally by Balassa (1961). The theory explains economic integration as both a process and a state of affairs implying the creation of measures designed to abolish discrimination between economic units belonging to different national states and the absence of various forms of discrimination between national economies respectively. Though the theory has undergone several revisions and modifications (Dragomanovic, 1969; Langhammer, 1977; Balassa and Stoutjesdijk, 1978), it still remains the backbone for the analysis of regional integration processes. Balassa's theory identifies five stages of integration with complexity of process increasing from the first to the last. The five stages are : a Free Trade Area (FTA), which abolishes tariffs and quotas for member countries but imposes tariffs and quotas against non-members; a Customs Union (CU), which is an upgrade on the FTA that allows non-member countries to trade with members via common tariffs and quotas; a Common Market (CM), which is a CU that abolishes non-tariff barriers to trade (product and services markets integration) as well as restrictions on factor movement (factor market integration); an economic union, where, besides the free circulation of products and factors of production, member states undertake 'some degree of harmonization of national economic policies, in order to remove discrimination that was due to disparities in these policies'; and total economic integration (TEI), which entails 'the unification of monetary, fiscal, social, and countercyclical policies' and 'the setting up of a supra-national authority whose decisions are binding for the member states' (Balassa, 1961).

Balassa's theory essentially describes an inverse relationship between integration and discrimination, such that progress in integration represents reduction of discriminations. Balassa's stages are generally accepted as the standard framework for regional integration, but Bolaños (2016) argues that while the theory has proved to be effective in the European Union, its success elsewhere is under debate. Also, it is not cast in stone that economic integration processes must begin with an FTA, nor that an FTA would necessarily progress to higher stages (Sapir, 2011). Evidence exists that many countries enter into FTAs but only a few are willing to release rights to determine their trade policies (Bolaños, 2016). Balassa's traditional framework is not applicable to all regional integration projects because of regional differences 
and peculiarities. Hence, it is now in vogue to split and analyze regional integration from at least three angles namely economic integration, which includes different degrees or stages of integration - preferential trade agreements, free trade areas (FTAs), customs unions (CUs), common markets (CMs), and economic and monetary unions; political integration or regional governance, which refers to greater depth, coordination, and harmonization of actions among members in the governmental and institutional spheres; and physical integration, majoring on the use of regional infrastructure projects as key drivers of integration (ECLAC, 2009). All three dimensions are related intimately to each other and are observable in varying degrees in all regional integration experiences all over the world (Bolaños, 2016). This paper focuses on an analysis of economic integration at its most basic form, the Free Trade Area.

\subsection{Nigeria's Trade Relations}

The general trend in Nigeria's export, import and trade balance from 1996 to 2018 is shown in Figure 1. In virtually all the time periods, total exports have been more than double that of total imports and this is largely due to the dominance of crude oil in total exports. Over a 30-year period (1981-2010), as obtained from the CBN data, crude oil continued to account for more than $90 \%$ of Nigeria's total export, an indication of a sustained level of structural rigidity to external trade in Nigeria (Orya,2020).

Between 1996 and 2003, total exports increased steadily but slowly, while imports were almost constant throughout the period. From 2003, Nigeria witnessed a sudden and pronounced upsurge in total exports which later nosedived from US $\$ 82$ billion in 2008 to US $\$ 50$ billion in 2009 . The fall in export was largely due to the global financial crisis of 2007/2008 which led to a cut down in the demand for crude oil, the main component of Nigeria's foreign earnings and revenue. Subsequently, exports later picked up and increased sharply through the years reaching an all-time high value of US\$143billion in 2012. The export boom was partly due to the growth in the non-oil sector which according to CBN (2013) increased at an average rate of 23 percent annually as opposed to less than 10 percent which has been the trend for over 3 decades following the discovery of crude oil in Nigeria. This improvement can be attributed to the strategic policies and programmes put in place by the Ministry of Industry, Trade and investment to drive developments in non-oil sector and expand the export base of the Nigerian economy (Agbaeze et al, 2015).

1n 2013, exports however contracted by 37\%, plummeting to a record low of US\$35billion in 2016 since the last decade. This period in Nigeria witnessed a collapse in the international price of crude oil particularly in 2014-2015 along with other internal crises notable among which are the recurring youth restiveness in the Niger Delta region and insurgency in some parts of the Northern region. Beyond this period, exports increased again due to a rebound in oil production. This cyclical pattern of export growth in Nigeria can be attributed to overt reliance on a highly volatile commodity, a situation which makes a strong case for the need to expand the country's narrow export base through diversification.

On the other hand, growth in imports was almost muted between 1996 and 2002 but afterwards witnessed a steady rise which later dropped sharply by $31 \%$ from US $\$ 63.97$ billion in 2011 to US $\$ 35.97$ billion in 2012. For almost three decades (1996-2014), Nigeria continued to enjoy trade surplus as exports clearly exceeded imports with the only deficit recorded in 2016. Although imports were greater than exports in both years, imports saw a continuous decrease from 2014 through 2017. The decline which affected both oil and non-oil imports was as a result of the reduction on fuel importation stemming from the resuscitation of domestic refineries (CBN 2015).

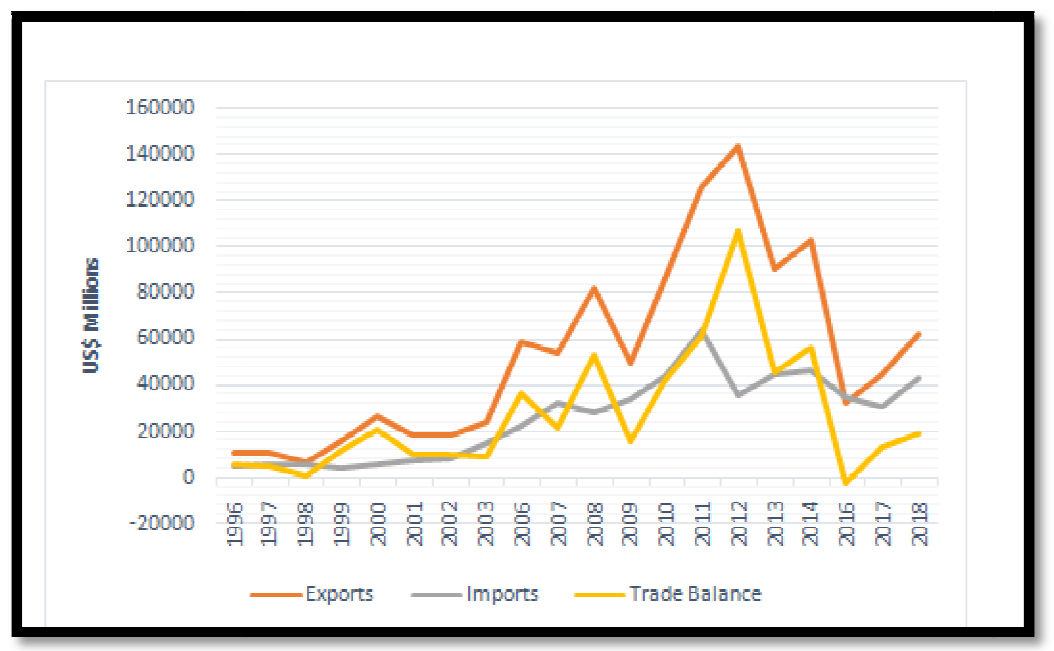

Figure 1: Nigeria's Exports, Imports and Trade Balance, 1996-2018 Source: Authors' Plot Based on WTS (2018) Data

\subsubsection{Nigeria's Major Trading Partners}

Nigeria' import source and export destination markets are highly concentrated in few countries with more than half of both imports and exports originating from and delivered to only five countries. Figures 2 and 3 show the top five trade partners of Nigeria in 2018. About $51.06 \%$ of Nigeria's total exports was destined for India (US\$9.91), Netherlands (US\$6.70), Spain (US\$6.32), France (US\$4.95) and South Africa (US\$3.98) while 57.45\% of import originated from China (US\$8.32), Netherlands (US\$4.91), Korea (US\$4.66), Belgium (US\$3.64) and United States (US\$3.16). As revealed by 
international trade centre (2019), the major import commodities are Machinery (18.9\% of total imports), mineral fuels (15.6\%), vehicles and electrical equipment (19.8\%), technical and medical apparatus (7.1\%), plastics, glass and plastic articles (6.4\%). Exports from Nigeria are basically primary commodities consisting of mineral fuels (87.1\%), Ships, boats and other metal goods $(9.8 \%)$, Cocoa $(0.6 \%)$, Oil seeds $(0.6 \%)$, fertilizers $(0.3 \%)$ and Fruit and Nuts $(0.2 \%)$. The export of mainly primary products indicates a narrow external trade channel for Nigeria, a precondition for economic shocks, poor governance and civil unrest. Global prices of primary commodities are subject to wide variabilities which repeatedly produce periods of economic boom and bust (Collier, 2002). For example, the 2020 budget was reviewed downward due to the pandemic and largely as a result of global oil crisis. Accordingly, oil bench mark was reduced from $\$ 57$ per barrel to $\$ 30$ per barrel and projected revenue cut down by $\$ 3$.3trillion, with negative implications on the overall outlook of the economy. Owing to the price swings of crude oil in the global market, which is Nigeria's main stay, and the gradual replacement of fossil fuel energy sources with clean energies, there is an urgent need for the diversification of the Nigeria's export base to allow for higher-valued agricultural products and manufactured goods which account for the highest share of global trade.

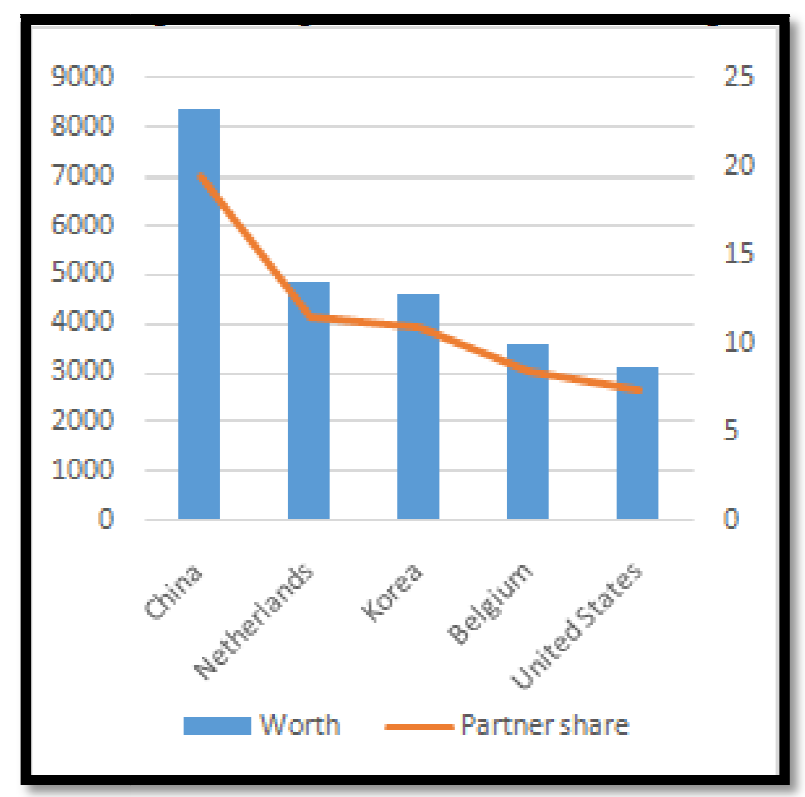

Figure 2: Nigeria's Top Five Import Sources (2018) Source: Authors' Plot from WITS (2020)

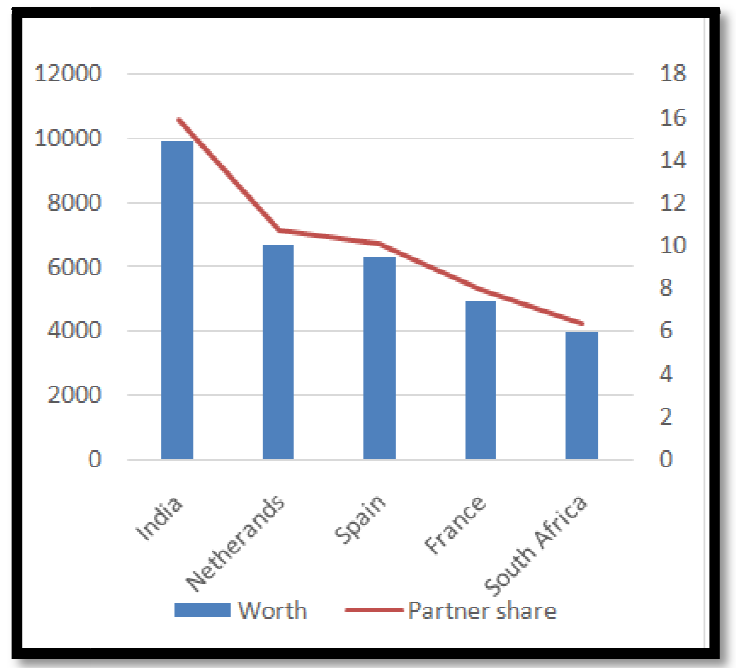

Figure 3: Top Five Destinations of Nigeria's Export (2018)

\subsubsection{Nigeria and Intra-Africa Trade in Context}

Nigeria has the largest economy in Africa with a gross domestic product (GDP) of over \$US 400 billion, representing about one-sixth of the continent's GDP. With a population of over 200 million consisting of a teeming youth population which is considered one of the largest in the world, Nigeria remains a key player in intra-African trade. Albeit, Nigeria's large and lucrative consumer market, the potential of intra-African trade is still largely underexplored. In 2018, for example, Nigeria's imports from and exports to the rest of Africa were US\$7 billion and US\$1.3 billion, respectively accounting for $13 \%$ and $4 \%$ of total merchandise exports and imports, respectively (Tralac, 2019). It should however be noted that although there is a relatively large variation between Nigeria's export and Imports to the rest of Africa, there is however a blooming informal cross-border trade of manufactured goods and agricultural commodities that exist within 
the ECOWAS region and surrounding countries in central Africa, particularly those along the border of Cameroon (Afreximbank, 2019). Informal trade continues to constitute a serious threat to regional trade in Nigeria as the present administration is particularly intent on curbing the smuggling of goods into and out of Nigeria.

As concerns licit trade in Africa, about $80 \%$ of Nigeria's Intra-African exports in 2018 was crude oil while the rest were floating structures for breaking up (3\%), electric energy (2\%) and Petroleum gas (1\%) (Tralac, 2019). The imported products were basically non-crude petroleum oil (18\%), fertilizers (7\%) and propylene polymers (7\%). Nigeria primarily trades with South Africa, Ivory Coast, Togo and Senegal. In fact, no African country made the list of Nigeria's top ten trade partners except for South Africa which remains a major destination market for Nigeria's exports. Majority of Nigeria's trade activities are done with Europe and Asia, a reflection of low intra-African trade. South Africa is Nigeria's largest trade partner in Africa accounting for $46 \%$ of the country's total intra-African trade (Tralac, 2019). Nigeria's share of total South African trade doubled from 6\% in 2017 to $12 \%$ in 2018 (Afreximbank (2019).

\subsection{Informal Cross Border Trade (ICBT) between Nigeria and its Neighbours}

It is noteworthy that informal cross border trade (ICBT) between Nigeria and its neighbouring countries is not always a deliberate attempt to evade immigration and customs duties but is a response to structural, economic and policy issues along the west coast of Africa (NBS, 2016). Throughout West Africa, the informal sector is the largest, and is most obvious in Benin Republic where the informal sector is responsible for about 50\% of Gross Domestic Product (GDP) and $90 \%$ of employment (Golub and Mbaye, 2019). Also, the major share of informal cross-border trade in Sub-saharan West Africa involves major staple food commodities that have a direct impact on regional food security (cattle, maize and rice), low quality consumer goods and petrol products. Therefore, informal cross border trade is best perceived as a response to structural issues in which small businesses, peasants and herders attempt to ensure food security for their households and reduce poverty through economic activities that mitigate surpluses and shortages of staple foods and thus reduce their vulnerability to price vagaries.

While all countries in West Africa are engaged in some form of and in varying degrees of ICBT with Nigeria, the largest volume occurs mainly through the Benin-Togo corridor in the west and the Niger republic border in the North of Nigeria. There is stiff competition between Benin and Togo for informal access to the Nigerian market. Proximity and location disincentivize informal trade between Nigeria and Togo, but Togo still sustains substantial ICBT through a regime of lower taxes and tariffs, in such a way that imports, and re-exporting are still favourable (Golub, 2012). Hence, ICBT occurs between Nigeria and Togo via the Benin-Nigeria border. ICBT across Nigeria-Benin border majorly involves trade in goods subject to heavy protection in Nigeria, particularly used cars and rice, which are then re-exported to Nigeria and Benin's imports of petroleum products, which were until very recently heavily subsidized in Nigeria.

Informal cross border trade between Nigeria and its west African neighbours was estimated at N1, 090, 890.58 million (US\$ 6,912.96 million) between June 2013 and May 2014 (NBS, 2016). Total exports were N435, 278.08 (US\$2, 758.35 million), representing 39.9\%. Imports accounted for $\mathrm{N} 655,612.5$ million (US\$4, 154.61 million), implying a negative informal trade balance of $\mathrm{N} 220,334.43$ million (US\$1, 396.26 million). The major items traded are vegetable products (57.6\%), animal and animal products (12.6\%), transportation equipment $(8.6 \%)$ and food stuff $(6.4 \%)$. The highest level of exports from Nigeria was to Niger Republic, with an export value of N327, 659.09 billion (or 75.3\% of the total informal exports). Cameroon and Benin Republic accounted for the balance, as they recorded informal export values of N74, 307.61 million (or $17.1 \%$ of total) and N33, 311.39 million (or $7.7 \%$ of total), respectively. The total value of informal imports from Niger Republic was N501, 118.53 million, constituting about $76.4 \%$ of the total informal imports into the country during the survey period. Cameroon accounted for N94, 955.32 million (14.5 \%) while Benin Republic accounted for the balance of $9.1 \%$.

Informal Cross Border trade between Nigeria and its neighbours is driven by a number of factors. The major determining factor for ICBT is the high monetary and time costs of formal trade which create incentives for informal trade. These high costs of formal trade are manifest as high import duties at the borders of either countries; exorbitant processing and clearance fees; Listless restrictions including exchange controls, state monopolies, and export prohibitions, Time losses and inadequate border infrastructure, resulting in long delays at formal borders; Institutional and regulatory barriers to trade such as protectionism (Lesser and Moisé-Leeman, 2009; Afrika and Ajumbo, 2012; Bouet, et al. 2017; Nkendah, 2010 and Muluvi et al. 2012)

\subsubsection{Nigeria's Intra-Regional Trade in Context}

Applying a regional lens to Nigeria's trade relations, the country belongs to two regional economic communitiesThe Community of Sahel-Saharan States (CEN-SAD) and the Economic Community of West African States (ECOWAS). While CENSAD has 17 member states, ECOWAS has 24 members. According to ARII (2020), the level of integration recorded in CEN-SAD is low with the highest performer (Cote d'Ivoire) achieving a little above the average (0.5) while ECOWAS performed moderately well with an average regional score of 0.43 . ARII (2020) provides five dimensions to measure the extent to which each country is integrated with its neighbours. These are trade integration, infrastructure integration, productive integration, free movement of person's integration and macroeconomic integration. As shown in Table 1, Nigeria is more integrated in ECOWAS (0.46 classement global score) than in CEN-SAD (0.41) with the nation ranking $8^{\text {th }}$ and $5^{\text {th }}$ within the regional economic communities, respectively. However, further disaggregation of regional integration along the identified dimensions reveals varying outcomes. Apart from the 'free movement of persons' dimension, all other dimensions of regional integration were observed to be higher for Nigeria in CEN-SAD than in ECOWAS. Freer movement of persons between Nigeria and ECOWAS region is a consequence of the ECOWAS protocol which centres on the creation of a borderless medium for persons, goods and services within the region. Trade, infrastructure, productive and 
macroeconomic integration scores were higher for Nigeria in CENSAD region despite the fact that overall regional integration score was higher for ECOWAS. This paradox is as a result of the weakening of the total average for CEN-SAD by its poor performance in the free movement of persons dimension (0.19). Notwithstanding, the marked differentials between the two regions, the classement global score, a measure of the overall performance of Nigeria in regional integration, show that Nigeria is performing below $50 \%$ of its full potential. Howbeit, actual statistics on regional trade is expected to be significantly higher than reported ones giving the thriving informal cross border trade in the regions. For all intents, Nigeria's representation in regional trade has been dwindling over the years. For example, in 2015 Nigeria practically dominated the economy of ECOWAS, accounting for $60 \%$ of the region's trade and 79\% of its exports excluding re-exports (Adjovi and Niang, 2015). The declining performance have been attributed to fall in the international price of crude oil and the border closure. The global oil price shock of 2014 had an enormous effect on Nigeria's economy as crude oil accounts for 95 percent and 90 percent of total exports and foreign exchange, respectively (TRT World, 2020). The high volatility of crude oil price in world market triggered the need for diversification of the Nigerian economy, a move which birthed the Economic Recovery and Growth Plan (ERGP). An important policy focus of ERGP was that of growing agriculture's share of the GDP at the rate of 5.0\% in 2017 and increasing it to $8.4 \%$ in 2020 while strengthening the border security (FRN, 2017). Hence, the need for the first border closure in 2015. The decline in Nigeria's performance in regional trade can therefore be also attributed to the border closure which according to TRT World (2020) has led to the boycotting of Nigeria's products by ECOWAS countries as a retaliation to the country's border closure.

Moving forward, although Nigeria performed fairly on the average in trade and productive integration dimensions. Results from table 1 show that Nigeria needs to improve on infrastructural and macroeconomic integration dimensions. There is a need to improve infrastructure connections between economic hubs in Nigeria and other countries in the regions. This include the development of road, air and water ways linking the country with the regions. In a highly automated world, establishing strong economic links in finance, production, trade and social development requires well designed and well-connected infrastructure (AFII,2020). Also, soaring inflation rates in Nigeria, which is higher than that targeted in the region, constitute an important factor in the low score of Nigeria with respect to macroeconomic integration dimension. Differences in import duties between Nigeria and other countries in the region particularly Benin, Niger and Togo provide the right incentive for informal cross border trade against which the Federal government of Nigeria is trying hard to put protectionist measures to discontinue the imports of cheap products into the country which does not only stifle domestic production but also significantly reduce tax revenue. Since Nigeria's border closure is a major setback in the success recorded for AFCTA, efforts should be made by regional governments to stabilize macroeconomic policies so as to encourage sustained cross-border investments.

\begin{tabular}{|c|c|c|c|c|}
\hline Dimension & \multicolumn{2}{|c|}{ CEN-SAD (24) } & \multicolumn{2}{c|}{ ECOWAS (15) } \\
\hline & Nigeria's score & $\begin{array}{c}\text { Regional } \\
\text { average }\end{array}$ & Nigeria's score & $\begin{array}{c}\text { Regional } \\
\text { average }\end{array}$ \\
\hline Classement global & 0.41 & 0.38 & 0.46 & 0.43 \\
\hline Trade integration & 0.51 & 0.38 & 0.46 & 0.44 \\
\hline Infrastructure integration & 0.38 & 0.30 & 0.35 & 0.3 \\
\hline Productive integration & 0.62 & 0.26 & 0.54 & 0.22 \\
\hline Free movement of persons & 0.19 & 0.51 & 0.67 & 0.73 \\
\hline Macroeconomic integration & 0.35 & 0.5 & 0.27 & 0.47 \\
\hline Regional ranking & 8 th & & $5^{\text {th }}$ & \\
\hline
\end{tabular}

Table 1: Regional Integration between Nigeria, CEN-SAD and ECOWAS

*Note: Number of Member Countries in Parenthesis

Source: Authors' Construction from ARII (2020)

\subsubsection{The State of Intra-Regional Trade in Africa}

In terms of regional trade, Africa has 8 regional economic communities (RECs) which are the main building blocks of the African Union. These are Economic Community of West African States (ECOWAS), Southern African Development Community (SADC), Common Market for Eastern and Southern Africa (COMESA), Economic Community of Central African States (ECCAS), Arab Maghreb Union (AMU) East African Community (EAC) and Intergovernmental Authority on Development (IGAD). Results from figure 4 reveal that intra-regional trade deepened from the period 2010-2012 to period 2014-2016 in virtually all the RECs except for ECCAS, where it was observed to decrease by 50\%. Notwithstanding the recorded increase, intra-regional trade in Africa is still below its potential and it is considered one of the lowest in the world. Based on the UNCTAD statistics, the share of intra-regional trade in total trade for Africa, having the highest number of countries, is $15.4 \%$ compared to $61.7 \%$ in European Union, $40.3 \%$ in North American Free Trade Agreement (NAFTA) and 23.3\% in Association of South East Asian Nations (ASEAN) (United Nations, 2019).

With regard to trade with the rest of Africa for the periods 2010-2012 and 2014-2016, Figure 4 shows a decrease in trade relations for SADC (18.5\% to $15.1 \%$ ), CENSAD (47.4\% to $41.6 \%$ ), ECOWAS (53.4\% to $43.3 \%$ ), AMU (52.2\% to 48.2\%) and EAC. However, trade with other countries in Africa was shown to increase for COMESA (38.2\% to 40.5\%) and IGAD (49.6\% to 51\%) with the highest growth rate was recorded in ECCAS (66.1\% to 82.3\%). Of all the RECs, ECCAS is the least integrated with a share of regional trade (percentage of total trade) of 33.9\% in 2012-2012 and 17.7\% in 2014-2016. The weak integration observed in the region is as a result of inadequate infrastructure and the frequent conflicts and crises plaguing the region (Meyer, 2015). Figure 4 also shows the trade complementarity index across the various regions in the year 2016. The result shows the complementarity indexes for the RECs which is disappointingly low, particularly for 
ECCAS (7.8\%) and ECOWAS (19.8\%). A low trade complementarity index indicates a large discrepancy between the import needs and the export supply between the member states of the region. This explains why over $80 \%$ of the regions' total trade is still being done with the rest of the world (United Nations, 2019). Low complementarity may also imply that trade policies which focus on reducing transportation costs and tariffs, for example, have weak potential effect in facilitating regional trade in the short to medium run (United Nations, 2019). The problem of low trade complementarity can be solved through export diversification and measures which promotes industrializations which are important focal points of AFCTFTA. Accordingly, the continent's attention will have to be shifted from extractive commodities like minerals and oil, which have accounted for a larger percentage of exports, to a more sustainable and balanced export base.

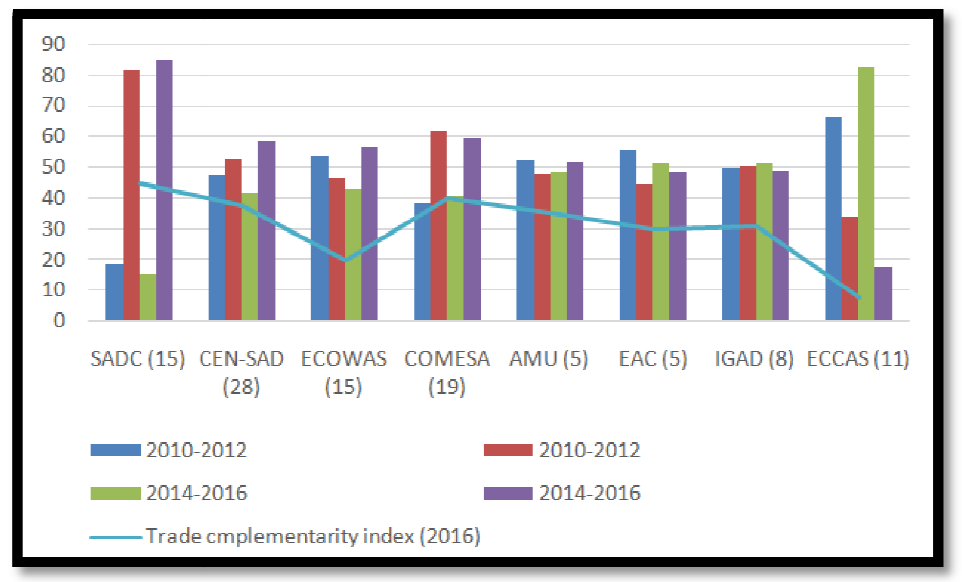

Figure 4: Share of RECS in Intra-Regional Trade and Total African Trade, 2010-2012 and 2014-2016 Sources: Authors' Plot Based on UNCTAD Computations from Data Sourced from Harvard University (2018)

\subsection{The Impact of Nigeria's Border Closure on AFCFTA}

The land border closure is a response to the age-long smuggling of goods into and out of Nigeria which poses serious threat to country's central goal of self-sufficiency. Border closures are not new in Africa, but Nigeria's actions render the seriousness and prospects of regional integration in Africa a little doubtful (Liedong, 2019). This in a way makes the objective of increasing intra-African trade by $60 \%$ in 2022 unrealistic following that the AFCFTA may be running parallel to Nigeria's aim of reducing food importation and strengthening the competitiveness of local industries. In the light of this, the Nigerian president has voiced legitimate concerns that AFCFTA could undermine local production activity and Nigeria could be a 'dumping ground' for cheap imports from outside the free trade area for Nigeria (Kassa and Zeufack, 2020).

Restriction of trade flows few months after signing the pact and the expression of support and understanding by the Director of African Department, International Monetary Fund (IMF), are indications of the low level of preparedness of African countries for the free trade agreement. Apart from diverting focus from areas that can enhance free trade agreement such as (trade data capture, transportation infrastructure, and border protection, the Nigeria's border closure may dampen the enthusiasm of other countries towards the free trade deal (Liedong, 2019). The ripple effect this could have on other African countries is largely due to the fact that Nigeria is one of the three largest economies in Africa (Nigeria- US\$376.284 billion; South Africa - US\$349.299 billion; and Egypt-US\$237.037 billion (Tshepidi,2019)) and her population of over 200 million makes it the largest single market in Africa. Nigeria's large population and economy is expected to provide a strong leverage for the practicality of AFCFTA and that was why the country's participation in the pact was considered a milestone achievement.

Dreams of an enhanced Intra African Trade and regional integration seems to be on the balance in recent times as border closures and squabbles among African countries are ostensibly increasing (AFRIC, 2019). The effect of the closure has been observed to be more pronounced on Nigeria's neighbouring countries. The Benin Republic, Nigeria's neighbour on the West, is the hardest hit as World Bank estimates that $80 \%$ of its imports goes into Nigeria and the remaining $20 \%$, representing the country's GDP and national income, is accounted for by the transit trade with Nigeria (Rodl and Partner, 2019). The effect of the trade war between Nigeria and Benin also extended to Ghana as the country's minister of Foreign affairs and regional integration recounts the country's loss to the border closure. It should be noted that Ghanaian traders in reaction to the ban, chased foreign shop owners from the country and blamed Nigeria for contravening ECOWAS provision of a free trade area between the member states (AFRIC, 2019). Niger Republic has also responded to the border closure by prohibiting the exportation of rice to Nigeria. It should however be noted that restriction of trade flows and the consequent disputes between affected countries discourages trade integration which is not only an important mechanism for promoting regional value chain to launch Africa into the global economy but also central in the reduction of poverty which is not only high but endemic in the continent.

\section{Conclusion and Policy recommendations}

The growing food import bill coupled with the low international competitiveness of local industries among other major factors created the urgent need for the land border closure in Nigeria. Nigeria has more unless being turned to a dumping sites for cheap goods smuggled from the neighbouring countries. These illegal trading activities tend to thwart the federal government's effort of attaining self -sufficiency as the availability of these cheap goods will encourage 
importation and stifle domestic production. It is in reaction to this that the restriction on the movement of goods was imposed. Although, it was earlier speculated that the ban would have been lifted early in year 2020, the stealth invasion of the Coronal virus pandemic which suddenly hit the world's population has not only disrupted the plans put in place but dampened all hopes of reopening the borders any time soon. Presently, coronal virus had plunged the world's economy into the opening stages of global recession due to the economic costs of the lock downs in most countries. This has led to monumental loss of income and GDP growth. Nigeria, like other countries of the world, might have to grapple with the challenges of the eventualities of coronal virus following its total eradication. As a coping strategy, more than ever, Nigeria should be considering AFCFTA as an important gateway out of the economic fallout which is inevitable. Based on the forgone, there is a need for all countries to retain their spots back on the map and one of the possible ways to solve the problem, especially for African countries, is to foster regional integration. As expected, this will help increase the share of Intra-African trade while increasing competitiveness at the enterprise and industry level through the provision of opportunities for large scale production, better allocation of resources and increased access to continental market. Apparently, AFCTA should be one of the important available options for Nigeria to cope with the imminent recession. The study therefore suggests the following recommendations as a guide in the implementation and achievement of the objectives of the trade agreement:

Following the concerns raised by the Nigerian government as regards smuggling of goods and weapons among other concerns, AFCFTA, alongside the member states, should employ state-of-the-art technologies that can help control smuggling and illegal migration across countries. This will go a long way in addressing some of the bottlenecks that may arise to threaten regional cohesion or prompt possible break away or exit from AFCFTA in the future.

Nigeria needs to improve on all the dimensions of regional trade highlighted in the study, if the country is to benefit significantly from the AFCFTA. More premium should be placed on trade and productive integrations as these two dimensions measure the extent of complementarity between exports and import goods available for trade with the rest of Africa. Nigeria needs to diversify its narrow export base.

Nigeria could sustain the closure of its land border that long because of the low correspondence between its exports and the import structure of the neighbouring countries, a condition which is not only peculiar to Nigeria but a common feature in all African trade relations. Accordingly, AFCTA should encourage member countries to diversify and specialize in the production of goods for which they have comparative advantage in order to deepen intra-African and intra-regional trade and for participating countries to benefit from economies of scale.

There is a need for AFCFTA to make clear provisions on the categories of goods and services that will or will not be totally free from tariffs or custom duties. This will prevent future squabbles between the participating states. There should also be a strong and effective dispute resolution mechanism which should not just be perceived as a formality but one which would be respected by all the participating countries based on strict and clear indications that erring parties will not be spared regardless of their economic/political stance or affiliations. For example, the position of the director of African Trade department of the IMF concerning Nigeria's border closure may weaken the perceived ability of the pact in enforcing its trade laws and regulations. Stricter laws should be enforced to ensure compliance among the member countries so that short-term and long terms goals of AFCTA can be realised. Individual rights of citizens of the participating countries should also be taken into consideration. In sum, in order for AFCTA not to become another failed move by the African continent, all member states should consider AFCFTA as the pathway to achieving their common goal of poverty reduction and welfare improvement.

Differences in import duties between Nigeria and other countries in the region particularly provides the right incentive for informal cross border trade. Since Nigeria's border closure is a major setback in the success recorded in the AFCTA, efforts should be made by regional governments to stabilize macroeconomic policies so as to encourage sustained cross-border investments.

\section{References}

i. Abia B.A (2020). Economic Implication of the Recent Border Closure. Centre for the Study of the Economics of Africa.

ii. Adeola G.I. and Oluyemi (2019). The Political and Security Implications of Cross Border Migration between Nigeria and Her Francophone Neighbours. International Journal of Social Science Tomorrow 1 (3);1-9.

iii. Afolayan, A.A. (2000). Trans-Border Movement and Trading. A case study of a borderland in southwestern Nigeria. pp 33-88

iv. Afrika, Jean-Guy K. and Ajumbo, Gerald (2012). Informal Cross Border Trade in Africa: Implications and Policy Recommendations. African Economic Brief, AfDB, Vol. 3 No. 10, November 2012, p. 8.

v. Association for Free Research and International Cooperation (AFRIC) (2019). Nigeria: Border Closure Extended, Impact on Transborder Trade, AFRIC Editorial, 8th November, 2019.

vi. Balassa, B. (1961a). The Theory of Economic Integration. Richard D. Irwin, Inc. Cited in Bolanos (2016).

vii. Balassa, B., and A. Stoutjesdijk (1978). 'Economic Integration among Developing Countries,' Journal of Common Market Studies, 14, 37-56.

viii. Bolaños, A.B. (2016). A step further in the theory of regional integration: A look at the Unasur's integration strategy. Gate Lyon-Saint-Etienne UMR5824.

ix. Bouët, A., Cosnard, L., and Laborde, D. (2017). Measuring trade integration in Africa. Journal of Economic Integration, 32(4): 937-977.

x. Chatham House (2015). Nigeria's Booming Borders The Drivers and Consequences of Unrecorded Trade. Available 
https://www.chathamhouse.org/sites/default/files/publications/research/20151207NigeriaBoomingBorders KoniHoffmannMelly.pdf.

xi. Codelice A. (2018). African Continental Free Trade Area: Opportunities and Challenges, THE FEDERALIST DEBATE Year XXXI, N³, November 2018

xii. Darma N.A. (2019). African Continental Free Trade Area (AfCFTA) Agreement and Nigeria's Economic Development: Prospects and Challenges. Paper Presented at NIQS 28th Biennial Conference/Election, Held at Civic Centre, Lagos. November 19-23, 2019.

xiii. Dragomanovic, V. (1969). Regional co-operation in industry (UNIDO monographs on industrial development, monograph no. 18). United Nations.

xiv. ECLAC (2009). Physical Infrastructure and Regional Integration, ECLAC Bulletin: Facilitation of trade and transport in Latin American and the Caribbean, 12(280), 1-4

xv. FRN (2014). 'Agricultural Investment Opportunities in Nigeria: Beef Processing Investment Case', Federal Ministry of Agriculture and Rural Development, Federal Republic of Nigeria, February 2014, http://nigerianagriculturenews.ng/wp-content/uploads/2014/02/130321_beef-Investment-Case_vHMA.pdf (accessed on 23 November 2015). Cited in Chatham House (2015).

xvi. Golub, S.S (2012). Entrepôt Trade and Smuggling in West Africa: Benin, Togo and Nigeria. World Economy.

xvii. Golub, Stephen \&Mbaye, Ahmadou. (2019). Chapter 8: Benin's informal trading with Nigeria.

xviii. Ighobor K. (2019). Africa set for a massive free trade area. Africa Renewal. August-November, 2018.

xix. International Monetary Fund (IMF) (2019). Sub-Saharan Africa: Recovery Amid Elevates Uncertainty. Regional Economic Outlook, IMF, April 2019.

xx. Kassa W. and Zeufack A. (2020). Nigeria's border closure: a road block or a speed bump on the road to a successful AfCFTA?African can end Poverty, World Bank Blog,2020.

xxi. Langhammer, R. J. (1977). 'Regional integration and cooperation in africa: A history of disappointments?,' Intereconomics, 12(9-10), 257-262.

xxii. Liedong T.A. (2019). Nigeria's border closure has implications for Africa's economic integration. The Conversation UK, October 27, 2019.

xxiii. Ministry of Livestock, Republic of Niger (2012). Les Statistiques du Secteur de l'Elevage, Rapport Annuel 2012, Ministry of Livestock, Republic of Niger

xxiv. Muluvi, A., Kamau, P., Githuku, S., and Ikiara, M. (2012). Kenya's trade within the East African Community: Institutional and regulatory barriers. In Accelerating Growth through Improved Intra-African Trade. M.S. Kimenyi , Z. A. Lewis and B. Routman (eds.) Brookings Africa Growth Initiative.

xxv. Onwuka O.N. and UdeGbunam, K.C. (2019). The African Continental Free Trade Area : Prospects and Challenges, African Cenntre for the Constructve Resoulution of disputes

xxvi. Rodl and partner (2019). Border Closure: Christmas Rice or Spaghetti?, WFO ROdl and Partner, 22nd November,2019.

xxvii. Sapir, A. (2011). 'European Integration at the Crossroads: A Review Essay on the 50th Anniversary of Bela Balassa's Theory of Economic Integration,' Journal of Economic Literature, 49(4), 1200-1229.

xxviii. Saygili M., Peters R. and Knebel, C. (2018). African COntinentel Free Trade Area: Challlenges and Opportunities of Tariff Reductions. UNCTADREsearch Paper NO. 15.

xxix. Signe L. and van der ven (2019). Nigeria's Benin border closure and what it means for the African Continental Free Trade Area (AfCFTA), Quartz Africa, November 4, 42019.

xxx. TShepidi M. (2019). The AFCFTA is a Giant Step Forward. The African Report, July-August, p. 8. 